\title{
Analisis Komponen Fisik Terhadap Kemampuan Shooting Pada Permainan Sepakbola Siswa MAN 2 Kota Makassar
}

\author{
Herman, Achmad Karim \\ Program Studi Pendidikan Jasmani, Kesehatan, dan Rekreasi STKIP YPUP Makassar \\ hermanm2mherman@gmail.com
}

Received: Januari 2021; Accepted: Februari 2021; Published: Maret 2021

Ed: Maret 2021; 8(1): 16-28

\begin{abstract}
Abstrak
Hasil penelitian menunjukkan bahwa; (1) Ada hubungan yang signifikan koordinasi mata kaki terhadap kemampuan shooting pada permainan sepak bola Siswa MAN 2 Kota Makassar, dengan nilai $r=0,751(\rho<\alpha=$ $0,05)$; (2) Ada hubungan yang signifikan kekuatan otot tungkai terhadap kemampuan shooting pada permainan sepak bola Siswa MAN 2 Kota Makassar, dengan nilai $r=0,657(\rho<\alpha=0,05)$;(3) Ada hubungan yang signifikan daya ledak otot tungkai terhadap kemampuan shooting pada permainan sepak bola Siswa MAN 2 Kota Makassar, dengan nilai $r=0,620(\rho<\alpha=0,05)$; (4) Ada hubungan yang signifikan secara bersama-sama antara koordinasi mata kaki, kekuatan otot tungkai dan daya ledak otot tungkai terhadap kemampuan shooting pada permainan sepak bola Siswa MAN 2 Kota Makassar, dengan nilai koefisien determinan $(\mathrm{R} 2)=0,679$ atau 67,9\%.
\end{abstract}

Kata Kunci: Koordinasi mata kaki, kekuatan otot tungkai, daya ledak tungkai, kemampuan Shooting.

\begin{abstract}
This research aimed to find out: (1) the correlation between leg eye coordinationAnd shooting ability in soccer games; (2) the correlation between leg muscle strength and shooting ability in soccer games; (3) the correlation between leg power explosion and shooting ability in soccer games; (4) the correlation betweenleg eye, leg muscle strength and leg power explosion on shooting ability in soccerfor the students of physical education department of MAN 2 Kota Makassar. Thetotal sample of the research was 30 students using simple random sampling technique. Technique of data analysis was descriptive correlation, regressive analysis on the significant level was $\alpha=0,05$ using SPSS version 21. The result of the research indicated that: (1) There is a significant correlation between leg eye coordination and shooting ability in soccer games, with a value of $r=0.751(\rho<=$ 0.05); (2) There is a significant correlation between leg muscle strength and shooting ability in soccer games, with a value of $r=0.657$ ( $\rho<=0.05$ ); (3) There is a significant correlation between leg power explosion and shooting ability in soccer games, with a value of $r=0.620(\rho<=0.05)$; (4) There is a significant correlation simultneously between leg eye, leg muscle strength and leg power explosion on shooting ability insoccer for the students of physical education department of MAN 2 Kota Makassar, with the determinant coefficient $(R 2)=$ 0.679 or $67.9 \%$.
\end{abstract}

Keywords: leg eye coordination, leg muscle strength, leg power explosion, shooting.

\section{PENDAHULUAN}

Sepakbola merupakan olahraga yang memerlukan banyak tenaga dalam memainkannya. Pemain dituntut mengerahkan semua tenaga yang dimilikinya selama permainan dimulai hingga peluit tanda berakhirnya permainan dibunyikan. Untuk dapat melakukan itu semua seorang pemain dituntut untuk memiliki kesegaran jasmani yang baik, karena dengan dukungan kesegaran jasmani yang baik diharapkan seorang pemain atau atlet akan dapat bermain dengan baik pula. Menurut 
Ismaryati (2011: 39) "kesegaran jasmani dibagi dalam 2 kategori yaitu kesegaran jasmani yang berhubungan dengan keterampilan adalah: kelincahan, keseimbangan, koordinasi, kecepatan, power, dan waktu reaksi. Komponen-komponen yang berhubungan dengan kesehatan adalah: daya tahan kardiorespirasi, komposisi tubuh, kelentukan, kekuatan otot dan daya tahan otot".

Dari banyak komponen kondisi fisik tersebut, pada cabang olahraga tertentu memerlukan prioritas kondisi fisik tertentu pula. Demikian pula pada cabang olahraga sepakbola, komponen kondisi fisik tersebut tentunya mempunyai peran yang berbeda-beda khususnya dalam mendukung kemampuan menggiring bola. "Komponen kondisi fisik pada cabang olahraga sepakbola yaitu kekuatan, kelincahan, kecepatan, ketahanan aerobik dan anaerobik dan kelentukan" Abdul Rahman (2012: 1-2).

Menurut Santoso Giriwijoyo (2015:72-73) latihan kekuatan otot ditinjau dari tipe kontraksi otot, latihan tahanan terbagi atas tiga kategori yaitu: Kontraksi isometrik, Kontraksi isotonik,dan Kontraksi isokinetik. Kekuatan adalah komponenen kondisi fisik yang menyangkut masalah seoarang atlet pada saat memprgunakan otot ototnya, menerima beban dalam waktu kerja tertentu. Dalam hal ini kekuatan otot tungkai dibutuhkan dalam mengiring bola pada saat akan melakukan gerakan shooting, karena pada saat akan melakukan gerakan bagian kaki khususnya tungkai akan mempergunakan otot ototnya untuk menerima beban dalam waktu kerja tertentu. Pada saat melakukan shooting bola Siswa MAN 2 Kota Makassar belum dapat menguasai bola tersebut secara baik, sehingga pada saat shooting seringkali bolanya jauh dan terlepas dari penguasaan. Pengertian kekuatan secara umum adalah kemampuan otot atau sekelompok otot untuk menguasai beban atau tahanan. Pengertian secara fisiologi, kekuatan adalah merupakan neuromuskuler untk mengatasi tahanan atau beban luar dan beban dalam. Agar menghasilkan tendangan yang baik dan akurat dibutuhkan koordinasi gerakan ayunan, pandangan mata,perkeenaan kaki dengan bola, dan tunjangan dengan kemampuan fisik yang prima khususnya daya ledak otot tugkai.

Daya ledak ialah kemampuan sebuah otot atau sekelompok otot untuk mengatasi tahanan beban dengan kekuatan dan kecepatan tinggi dalam suatu gerakan yang utuh. Dalam melakukan shooting daya ledak otot tungkai digunakan untuk menghasilkan tendangan yang cepat, kuat dan akurat. Daya ledak otot tungkai sangat diperlukan, karena seoarang pemain yang hendak shooting bola yang akan dituju maka salah satu aspek yang perlu diperhatikan adalah amasalah daya ledak otot tungkai. Daya ledak menurut kamus bahasa indonesia adalah: kekuatan, tenaga, pengaruh, jalan untuk sesuatu, melihat, tipu.

Berdasarkan pada pengertian tersebut daya ledak yang dimaksud dalam penelitian ini adalah kemampuan otot atau sekelompok otot seseorang untuk mempergunakan kekuatan maksimal yang ikerahkan dalam waktu yang sependek-pendeknya atau sesiingkat-singkatnya. hal tersebutlah yang menyebabkan tehnik didalam melakukan shooting kurang baik, sehingga banyak diantara siswa MAN 2 Kota Makassar tidak akurat dan belum maksimal dalam melakukan teknik shooting. Hal ini dapat dibuktikan dan dilihat dari bebrapa kali siswa MAN 2 Kota Makassar pada saat pembelajaran sering terjadi kesalahan dalam melakuakan shooting tidak tepat sasaran atau tidak sesuai tujuan yang di inginkan, sehingga didalam pertandingan teknik shooting ini merupakan kelemahan yang mendasar yang sering terjadi pada siswa MAN 2 Kota Makassar. Hal ini menuntut seorang pemain untuk memiliki kemampuan shooting yang baik. Dengan demikian untuk melakukan shooting dengan baik diduga banyak faktor yang mempengaruhinya, antara lain: koordinasi mata kaki, kekuatan otot tungkai, dan daya ledak otot tungkai.

Dari hasil observasi yang penulis lakukan di lapangan, pemain sepak bola siswa MAN 2 Kota Makassar sewaktu melakukan shooting kegawang bola sering kali tidak tepat sasaran atau 
keluar dari gawang, adapun sekali-kali mengarah kegawang tetapi shootingnya tidak keras dan kuat. Sehingga dengan mudah ditangkap oleh penjaga gawang.

\section{METODE}

Jenis penelitian ini adalah penelitian kuantitatif. Penelitian ini bertujuan untuk mengetahui; (1) Apakah ada hubungan koordinasi mata kaki terhadap kemampuan shooting pada permainan sepak bola Siswa MAN 2 Kota Makassar; (2) Apakah ada hubungan kekuatan otot tungkai terhadap kemampuan shootingpada permainan sepak bola Siswa MAN 2 Kota Makassar; (3) Apakah ada hubungan daya ledak otot tungkai terhadap kemampuan shooting pada permainan sepak bola Siswa MAN 2 Kota Makassar; (4) Apakah ada hubungan koordinasi mata kaki, kekuatan otot tungkai dan daya ledak otot tungkai secara bersama sama terhadap kemampuan shootingpada permainan sepak bola Siswa MAN 2 Kota Makassar.

Desain penelitian sebagai rancangan yang dijadikan sebagai acuan dalam melakukan penelitian. Penelitian ini adalah jenis penelitian yang bersifat deskriptif yang bertujuan untuk mengetahui hubungan koordnasi mata kaki, kekuatan otot tungkai, dan daya ledak otot tungkai terhadap kemampuan shootingdalam permainan sepakbola pada siswa MAN 2 Kota Makassar. Model desain penelitian yang digunakan.

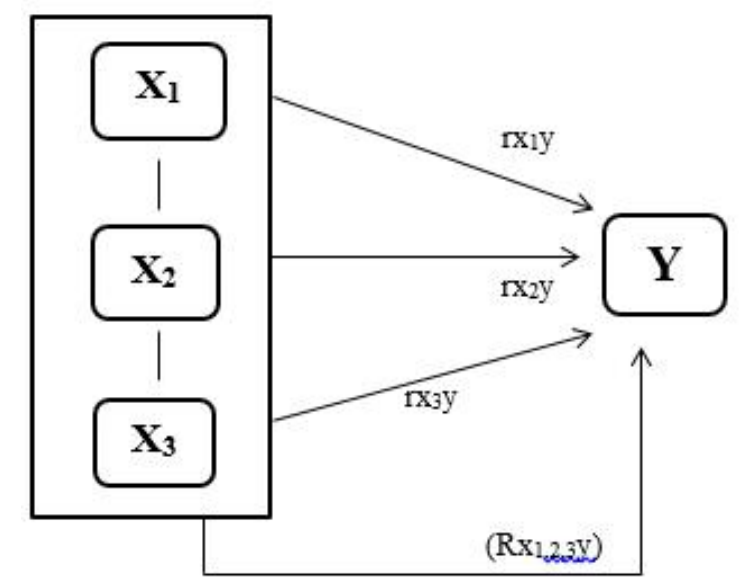

Gambar 1. Desain Penelitian, (Sugiyono, 2017:68)

Keterangan:

$\mathrm{X} 1 \quad$ : koordinasi mata kaki (variabel bebas)

$\mathrm{X} 2$ : kekuatan otot tungkai (variabel bebas)

X3 : daya ledak otot tungkai (variabel bebas)

$\mathrm{Y} \quad$ : kemampuan shooting dalam permainan sepakbola (variabe terikat)

Populasi penelitian ini adalah keseluruhan siswa MAN 2 Kota Makassar angkatan2017. Sampel yang digunakan adalah mahasiswa laki-laki sebanyak 30 orang. Dalam penelitian ini cara pengambilan sampelnya yaitu degan cara teknik simple random sampling dimana sampel diambil secara acak. Teknik analisis data yang digunakan dalam penelitian ini adalah analisis deskriptif, analisis korelasi, dan analisis regresi pada taraf signifikan $\alpha=0,05$ 


\section{HASIL DAN PEMBAHASAN}

\section{Deskripsi Data}

Untuk mendapatkan gambaran umum data suatu penelitian maka digunakanlah analisis data deskriptif terhadap koordinasi mata kaki, kekuatan otot tungkai dan daya ledak otot tungkai terhadap kemampuan shooting pada permainan sepak bola siswa MAN 2 Kota Makassar. Hasil analisis deskriptif data tersebut dapat dilihat pada tabel berikut:

Tabel 1. Hasil analisis deskriptif data

\begin{tabular}{|c|c|c|c|c|}
\hline \multirow[b]{2}{*}{ Statistik } & \multicolumn{4}{|c|}{ Variabel } \\
\hline & $\begin{array}{l}\text { Koordinasi } \\
\text { Mata Kaki } \\
\left(\mathrm{X}_{1}\right) \mathrm{Kali}\end{array}$ & $\begin{array}{c}\text { Kekuatan Otot } \\
\text { Tungkai }\left(\mathrm{X}_{2}\right) \\
\text { kali }\end{array}$ & $\begin{array}{c}\text { Daya Ledak } \\
\text { Otot Tungkai } \\
\left(\mathrm{X}_{3}\right) \mathrm{cm}\end{array}$ & $\begin{array}{l}\text { Shooting pada } \\
\text { permainan sepak } \\
\text { bola (Y) poin }\end{array}$ \\
\hline $\mathrm{N}$ & 30 & 30 & 30 & 30 \\
\hline Mean & 13.23 & 28.43 & 250.10 & 12.40 \\
\hline Median & 13.50 & 28.50 & 248.50 & 13.00 \\
\hline Mode & 11 & 22 & 260 & 13 \\
\hline Std. Deviation & 3.720 & 6.224 & 14.608 & 3.286 \\
\hline Variance & 13.840 & 38.737 & 213.403 & 10.800 \\
\hline Range & 12 & 24 & 49 & 14 \\
\hline Minimum & 7 & 19 & 225 & 7 \\
\hline Maximum & 19 & 43 & 274 & 21 \\
\hline Sum & 397 & 853 & 7503 & 372 \\
\hline
\end{tabular}

\section{Pengujian Persyaratan Analisis Data}

\section{Uji Normalitas Data}

Sebelum melakukan uji statistik, salah satu asumsi yang harus dipenuhi adalah data harus mengikuti sebaran normal, maka dilakukan uji normalitas data.Pengujian normalitas data dapat dilakukan untuk mengetahui apakah data yang diperoleh pada hasil penelitian berada pada sebaran normal. Pengujian normalitas data dapat dilakukan dengan uji Kolmogorov Smirnov.

Kriteria untuk menyatakan apakah data berasal dari sampel yang digunakan berdistribusi normal atau tidak dapat dilakukan dengan membandingkan koefisien Sig. Atau nilai P dengan 0,05 (taraf Signifikan). Apabila nilai $\mathrm{P}$ lebih besar dari 0,05 (taraf signifikan) yang berarti tidak signifikan, maka memiliki makna bahwa data berasal dari populasi yang berdistribusi normal. Sebaliknya apabila P-Value lebih kecil dari 0.05, maka memiliki makna bahwa data berasal dari populasi yang berdistribusikan tidak normal.

Adapun hasil pengujian normalitas data variabel koordinasi mata kaki, kekuatan otot tungkai dan daya ledak otot tungkai terhadap kemampuan shooting pada permainan sepak bola siswa MAN 2 Kota Makassar dapat dilihat dari tabel berikut. 
Tabel 2 Hasil Pengujian normalitas data

\begin{tabular}{|l|c|c|c|c|}
\hline \multicolumn{1}{|c|}{ Variabel } & KS-Z & $P$ & Sig. & Keterangan \\
\hline Koordinasi Mata Kaki & 0,574 & 0,897 & 0,05 & Normal \\
\hline Kekuatan Otot Tungkai & 0,599 & 0,865 & 0,05 & Normal \\
\hline Daya Ledak Otot Tungkai & 0,645 & 0,800 & 0,05 & Normal \\
\hline Shooting pada permainan sepak bola & 0,721 & 0,676 & 0,05 & Normal \\
\hline
\end{tabular}

\section{Pengujian Hipotesis}

Setelah dilakukan uji persyaratan normalitas data pada hipotesis yang akan di uji, maka selanjutnya dilakukan pengujian terhadap hipotesis, untuk membuktikan kebenarannya. Hasil perhitungan statistik pada hipotesis penelitian diuraikan sebagai berikut:

a. Hubungan koordinasi mata kaki terhadap kemampuan shooting pada permainan sepak bola siswa MAN 2 Kota Makassar.

Hipotesis yang pertama diuji dalam penelitian ini yaitu "ada hubungan koordinasi mata kaki terhadap kemampuan shooting pada permainan sepak bola siswa MAN 2 Kota Makassar", untuk mengetahui kebenarannya maka perlu dilakukan pengujian analisis korelasi tunggal.

Tabel 3 Hasil uji korelasi

\begin{tabular}{|c|c|c|c|c|}
\hline Variabel & $\mathrm{N}$ & $r$ & $\mathrm{P}_{\text {value }}$ & Keterangan \\
\hline $\begin{array}{c}\text { Koordinasi mata kaki }\left(\mathrm{X}_{1}\right) \\
\text { terhadap shooting pada } \\
\text { permainan sepak bola (Y) }\end{array}$ & 30 & 0,751 & 0,000 & Signifikan \\
\hline
\end{tabular}

Keterangan:

$\mathrm{r} \quad=$ Koefisien Korelasi

Pvalue $=$ Nilai Probabilitas

$\mathrm{N} \quad=$ Banyaknya Data

Secara statistik hipotesis dapat dirumuskan sebagai berikut:

$$
\begin{aligned}
& H_{0}: r x_{1} y=0 \\
& H_{1}: r x_{1} y \neq 0
\end{aligned}
$$

Berdasarkan hasil dari pengujian analisis korelasional data koordinasi mata kaki terhadap kemampuan shooting pada permainan sepak bola. Maka memperoleh nilai korelasi $(\mathrm{r})=0,751$ dengan tingkat probabilitas $(0,000)$ kurang dari $\alpha$ 0,05. Maka H0 ditolak dan H1 diterima atau koefisien korelasi signifikan, atau koordinasi mata kaki berhubungan secara signifikan terhadap kemampuan shooting pada permainan sepak bola. Sehingga dapat disimpulkan bahwa ada hubungan yang signifikan antara koordinasi mata kaki terhadap kemampuan shootingpada permainan sepak bola. 


\section{b. Hubungan kekuatan otot tungkai terhadap shooting pada permainan sepak bola siswa MAN 2 Kota Makassar.}

Hipotesis yang kedua diuji dalam penelitian ini yaitu "ada hubungan kekuatan otot tungkai terhadap kemampuan shooting pada permainan sepak bola siswa MAN 2 Kota Makassar", untuk mengetahui kebenarannya maka perlu dilakukan pengujian analisis korelasi tunggal.

Tabel 4 Hasil uji korelasi.

\begin{tabular}{|l|c|c|c|c|}
\hline Variabel & $\mathrm{N}$ & $r$ & $\mathrm{P}_{\text {value }}$ & Keterangan \\
\hline $\begin{array}{l}\text { Kekuatan otot tungkai }\left(\mathrm{X}_{2}\right) \\
\text { terhadap kemampuan shooting } \\
\text { pada permainan sepak bola (Y) }\end{array}$ & 30 & 0,657 & 0,000 & Signifikan \\
\hline
\end{tabular}

Keterangan:

$$
\begin{array}{ll}
r & =\text { Koefisien Korelasi } \\
\mathrm{P}_{\text {value }} & =\text { Nilai Probabilitas } \\
\mathrm{N} & =\text { Banyaknya Data }
\end{array}
$$

Secara statistik hipotesis dapat dirumuskan sebagai berikut:

$$
\begin{aligned}
& H_{0}: r x_{2} y=0 \\
& H_{1}: r x_{2} . y \neq 0
\end{aligned}
$$

Berdasarkan hasil dari pengujian analisis korelasional data kekuatan otot tungkai terhadap kemampuan shooting pada permainan sepak bola. Maka memperoleh nilai korelasi $(r)=0,657$ dengan tingkat probabilitas $(0,000)$ kurang dari $\alpha 0,05$. Maka H0 ditolak dan H1 diterima atau koefisien korelasi signifikan, atau kekuatan otot tungkai berhubungan secara signifikan terhadap kemampuan shooting pada permainan sepak bola. Sehingga dapat disimpulkan bahwa ada hubungan yang signifikan antara kekuatan otot tungkai terhadap kemampuan shooting pada permainan sepak bola.

\section{c. Hubungan daya ledak otot tungkai terhadap kemampuan shooting pada permainan sepak bola siswa MAN 2 Kota Makassar.}

Hipotesis yang ketiga diuji dalam penelitian ini yaitu "ada hubungan daya ledak otot tungkai terhadap kemampuan shooting pada permainan sepak bola siswa MAN 2 Kota Makassar", untuk mengetahui kebenarannya maka perlu dilakukan pengujian analisis korelasi tunggal.

Tabel 5 Hasil uji korelasi.

\begin{tabular}{|c|c|c|c|c|}
\hline Variabel & $\mathrm{N}$ & $r$ & $\mathrm{P}_{\text {value }}$ & Keterangan \\
\hline $\begin{array}{c}\text { Daya ledak otot tungkai }\left(\mathrm{X}_{3}\right) \\
\text { terhadap shooting pada } \\
\text { permainan sepak bola (Y) }\end{array}$ & 30 & 0,620 & 0,000 & Signifikan \\
\hline
\end{tabular}

Keterangan:

$$
\begin{array}{ll}
r & =\text { Koefisien Korelasi } \\
\mathrm{P}_{\text {value }} & =\text { Nilai Probabilitas } \\
\mathrm{N} & =\text { Banyaknya Data }
\end{array}
$$


Secara statistik hipotesis dapat dirumuskan sebagai berikut:

$$
\begin{aligned}
& H_{0}: r x_{1} y=0 \\
& H_{1}: r x_{1} y \neq 0
\end{aligned}
$$

Berdasarkan hasil dari pengujian analisis korelasional data daya ledak otot tungkai terhadap kemampuan shooting pada permainan sepak bola. Maka memperoleh nilai korelasi $(r)=0,620$ dengan tingkat probabilitas $(0,000)$ kurang dari $\alpha 0,05$. Maka H0 ditolak dan H1 diterima atau koefisien korelasi signifikan, atau daya ledak otot tungkai berhubungan secara signifikan terhadap kemampuan shooting pada permainan sepak bola. Sehingga dapat disimpulkan bahwa ada hubungan yang signifikan antara daya ledak otot tungkai terhadap kemampuan shooting pada permainan sepak bola.

\section{d. Hubungan koordinasi mata kaki,kekuatan otot tungkai dan daya ledak otot tungkai secara bersama-sama terhadap kemampuan shooting pada permainan sepak bola siswa MAN 2 Kota Makassar.}

Hipotesis yang ketiga diuji dalam penelitian ini yaitu "ada hubungan koordinasi mata kaki, kekuatan otot tungkai dan daya ledak otot tungkai terhadap kemampuan shooting pada permainan sepak bola siswa MAN 2 Kota Makassar", untuk mengetahui kebenarannya maka perlu dilakukan pengujian analisis regresi ganda.

Tabel 6 Hasil uji korelasi ganda

\begin{tabular}{|l|c|c|c|c|c|c|}
\hline \multicolumn{1}{|c|}{ Variabel } & $\mathrm{N}$ & $\mathrm{R}$ & $\mathrm{R}^{2}$ & $\mathrm{~F}$ & $\mathrm{P}_{\text {value }}$ & Keterangan \\
\hline $\begin{array}{l}\text { Koordinasi mata kaki } \\
\left(\mathrm{X}_{1}\right) \text { Kekuatan otot } \\
\text { tungkai (X) Daya } \\
\text { ledak otot tungkai(X) } \\
\text { terhadap kemampuan } \\
\text { shooting pada } \\
\text { permainan sepak bola } \\
\text { (Y) }\end{array}$ & 30 & 0,824 & 0,679 & 18,349 & 0,000 & Signifikan \\
\hline
\end{tabular}

Keterangan:

$\mathrm{R}=$ Koefisien regresi

$\mathrm{R}^{2} \quad=$ Koefisien determinan

$\mathrm{F} \quad=$ Nilai $\mathrm{F}$ hitung

$\mathrm{P}_{\text {value }} \quad=$ Nilai Probabilitas

$\mathrm{N} \quad=$ Banyaknya Data

Secara statistik hipotesis dapat dirumuskan sebagai berikut:

$$
\begin{aligned}
& H_{0}: R x_{1.2} y=0 \\
& H_{1}: R x_{1.2 .} y \neq 0
\end{aligned}
$$

Berdasarkan hasil analisis regresi diperoleh nilai $\mathrm{F}$ sebesar 18,349. Sehingga hasil regresi yang didapatkan adalah signifikan. Dengan demikian perlu dilihat persamaan regresinya. Berdasarkan persamaan regresi $\hat{Y}=-3,722+0,463 X_{1}+0,189 X_{2}+0,019 X_{3}$ dapat dikemukakan bahwa setiap peningkatan skor rata-rata koordinasi mata kaki, maka akan diperoleh shooting pada 
permainan sepak bola sebesar $0,463 \mathrm{X}_{1}$, setiap dalam peningkatan skor rata-rata kekuatan otot tungkai, maka akan diikuti oleh shooting pada permainan sepak bola sebesar $0,189 \mathrm{X}_{2}$,setiap dalam peningkatan skor rata-rata daya ledak otot tungkai, maka akan diikuti oleh shooting pada permainan sepak bola sebesar $0,019 \mathrm{X}_{3}$. Hasil analisis korelasi diperoleh nilai sebesar 0,679. Hal ini menunjukkan bahwa terdapat hubungan secara bersama-sama yang signifikan antara koordinasi mata kaki, kekuatan otot tungkai dan daya ledak otot tungkai terhadap kemampuan shooting pada permainan sepak bola siswa MAN 2 Kota Makassar

\section{PEMBAHASAN HASIL PENELITIAN}

Hasil analisis data dan pengujian hipotesis yang telah di kemukakan sebelumnya, maka menunjukkan bahwa dari empat hipotesis yang diajukan terdapat hubungan yang signifikan. Dengan kata lain ada empat hipotesis yang diterima dan menunjukkan ada hubungan yang signifikan. Dari hasil tersebut, tentang koordinasi mata kaki,kekuatan otot tungkai dan daya ledak otot tungkai terhadap kemampuan shooting pada permainan sepak bola pada penelitian ini relavan dengan kerangka berpikir kemudian telah dikembangkan berdasarkan teori-teori yang mendukung dalam penelitian ini, sehingga dapat dijabarkan sebagai berikut.

\section{Ada hubungan langsung koordinasi mata kaki terhadap kemampuan shooting pada permainan sepak bola siswa MAN 2 Kota Makassar.}

Dari hasil pengujian hipotesis pertama variabel menunjukkan ada hubungan yang signifikan antara koordinasi mata kaki (X1) terhadap shooting pada permainan sepak bola (Y). Berdasarkan hasil perhitungan diperoleh nilai koefisien korelasi $(r)=0,751$, sehingga dapat membuktikan bahwa teknik shooting pada permainan sepak bola sangat membutuhkan komponen-komponen anggota tubuh seperti koordinasi mata kaki, dimana komponen-komponen tersebut sangat membantu dalam proses melakukan shooting. Karena pada saat seseorang melakukan shooting pada permainan sepak bola membutuhkan koordinasi mata kaki yang baik agar labih mudah dalam mengarahkan bola kedaerah gawang lawan pada permainan sepak bola.

Hal tersebut berkaitan erat dengan teori yang dikemukakan oleh Widiastuti (2017:17) "koordinasi merupakan kemampuan untuk melakukan gerakan atau kerja dengan tepat dan efisien. Koordinasi mata tangan merupakan kemampuan biomotorik yang melibatkan beberapa unsurunsur kondisi fisik lainnya"

Menurut Fenanlampir dan Faruq (2015:158) "koordinasi adalah suatu kemampuan motorik yang sangat kompleks. Koordinasi didefinisikan sebagai hubungan yang harmonis dari hubungan saling pengaruh diantara kelompok-kelompok otot selama melakukan kerja, yang ditunjukkan dengan berbegai tingkat keterampilan”. Sedangkan Menurut Djoko Pekik (2012:77) koordinasi adalah kemampuan melakukan gerak pada berbagai tingkat kesukaran dengan cepat dan tepat secara efisien. Tingkatan baik atau tidaknnya koordinasi gerak seseorang tercermin dalam kemampuannya untuk melakukan suatu gerakan dengan trampil. Seorang atlet dengan koordinasi yang baik bukan hanya mampu melakukan suatu ketrampilan secara sempurna, akan tetapi juga mudah dan cepat dalam melakukan ketrampilan yang masih baru baginnya. Koordinasi yang baik dapat mengubah dan berpindah secara cepat dari pola gerak satu kepola gerak yang satu kepola gerak yang lain sehingga gerakannya menjadi efektif.

\section{Ada hubungan langsung kekuatan otot tungkai terhadap kemampuan shooting pada}




\section{permainan sepak bola siswa MAN 2 Kota Makassar.}

Dari hasil pengujian hipotesis kedua menunjukkan ada hubungan yang signifikan antara kekuatan otot tungkai (X2) terhadap kemampuan shooting pada permainan sepak bola (Y). Berdasarkan hasil perhitungan diperoleh nilai koefisien korelasi $(r)=0,657$, sehingga temuan ini membuktikan bahwa dalam melakukan shooting, kekuatan otot tungkai merupakan faktor penunjang atau faktor pendukung dalam pelaksanaan shooting bola pada permainan sepak bola.

Hal ini sejalan dengan yang dikemukakan oleh Widiastuti (2017:15) kekuatan otot adalah kemampuan otot atau sekelompok otot untuk melakukan satu kali kontraksi secara maksimal melewan tahanan atau beban. Secara mekanis kekuatan otot didefinisikan sebagai gaya (force) yang dapat dihasilkan oleh otot atau sekelompok otot dalam suatu kontraksi maksimal. Kekuatan otot merupakan hal penting untuk setiap orang. Sedangkan Menurut Ismaryati, dkk (2018:111) kekuatan adalah tenaga kontraksi ototyang dicapai dalam sekali usaha maksimal. Usaha maksimal ini dilakukan oleh otot atau sekelompok otot untuk mengatasi suatu tahanan. Kekuatan merupakan unsur yang sangat penting dalam aktivitas olahraga, karena kekuatan merupakan daya penggerak, dan pencegah cedera. Selain itu kekuatan memainkan peranan penting dalam komponen-komponen kemampuan fisik yang lain misalnya power, kelincahan kecepatan. Dengan demikian kekuatan merupakan faktor utama untuk menciptakan prestasi yang optimal.

Adapun teori yang dikemukakan oleh Nur Ichsan Halim (2011:27) kekuatan otot merupakan komponen biomotorik yang diperlukan oleh semua cabang olahraga dengan tingkatan yang berbeda satu dengan lainnya. Komponen ini dapat ditingkatkan dengan cara memberikan tahanan yang internal maupun eksternal terhadap otot bersangkutan.

Menurut Mulyono Biyakto Atmojo (2015:58) kekuatan otot adalah kemampuan suatu otot menggerakkan kekuatan. Sedangkan menurut Sofyan (2016:52) kekuatan adalah kemampuan otot untuk mengatasi hamabatan atau beban selama bekerja dan juga sebagai penggerak dalam aktifitas fisik ,sehingga kekuatan berperan penting dalam melindungi otot otot manusia.

\section{Ada hubungan langsung daya ledak otot tungkai terhadap kemampuan shooting pada permainan sepak bola siswa MAN 2 Kota Makassar.}

Dari hasil pengujian hipotesis pertama variabel menunjukkan ada hubungan yang signifikan antara daya ledak otot tungkai (X3) terhadap shooting pada permainan sepak bola (Y). Berdasarkan hasil perhitungan diperoleh nilai koefisien korelasi $(r)=0,620$, sehingga dapat membuktikan bahwa teknik shooting pada permainan sepak bola sangat membutuhkan dua komponen anggota tubuh seperti daya ledak otot tungkai, dimana komponen-komponen tersebut sangat membantu dalam proses melakukan shooting. Karena pada saat seseorang melakukan shooting bolamembutuhkan daya ledak otot tungkai yang baik agar labih mudah dalam melakukan shooting pada permainan sepak bola.

Hal ini sejalan dengan yang dikemukakan oleh Widiastuti (2017:16) "Daya eksplosif (Power) adalah gabungan antara kekuatan dan kecepatan atau pengerahan gaya otot maksimum dengan kecepatan maksimum.” Dan teori yang dikemukakan Mulyono Biyakto Atmojo (2015:62) "power adalah kemampuan untuk mengarahkan kekuatan dengan maksimum dalam jangka waktu yang minim".

Menurut Nur Ichsan Halim (2011:16) daya otot ledak tungkai adalah kemampuan seseorang untuk mempergunakan kekuatan maksimum yang dikerahkan dalam waktu sesingkatsingkatnya.dalam hal ini dapat dinyatakan bahwa daya ledak (power) =kekuatan (force) $\mathrm{x}$ kecepatan (velocity), seperti dalam lompat jauh,tolak peluru,lari spint 100meter serta gerak lain yang bersifat ekslosif. Sedangkan menurut Irwadi (2011:96) mengartikan daya ledak otot sebagai 
kemampuan seseorang untuk menggerakan tubuh atau bagian bagiannya secara kuat dan kecepatan tinggi. Wujud nyata dari ledak otot tergambar dalam kemampuan seseorang seperti,kekuatan atau ketinggian loncat,atau kekuatan tendangan, kekuatan lemparan, dan kekuatan dorongan.

Daya ledak sering pula disebut kekuatan ekslosif,ditandai adanya gerakan atau perubahan tiba-tiba yang cepat dimana tubuh terdorong keatas (vertical) atau ke depan (horizontal) dengan mengerahkan kekuatan otot maksimal.Dalam daya ledak ini termasuk pula gerakan tiba-tiba dan cepat dari lengan ketika memukul atau menyemes bola serta tungkai tatkala menyepak.

4. Ada hubungan koordinasi mata kaki,kekuatan otot tungkai dan daya ledak otot tungkaisecara bersama-sama terhadap kemampuan shooting pada permainan sepak bola siswa MAN 2 Kota Makassar.

Dari hasil pengujian hipotesis keempat menunjukkan terdapat hubungan yang signifikan antara koordinasi mata kaki (X1),kekuatan otot tungkai (X2) dan daya ledak otot tungkai (X3) terhadap kemampuan shooting pada permainan sepak bola (Y). Berdasarkan hasil perhitungan diperoleh nilai regresi $\mathrm{R}=0,824$ yang dijelaskan melalui persamaan regresi $\hat{\mathrm{Y}}=-3,722+0,463 \mathrm{X} 1$ $+0,189 \mathrm{X} 2+0,019 \mathrm{X} 3$, untuk nilai R2 (koefisien determinan) $=0,679$. Hal ini berarti $0,679 \times 100 \%$ $=67,9 \%$ shooting pada permainan sepak bola, koordinasi mata kaki, kekuatan otot tungkai dan daya ledak otot tungkai. Untuk sisanya $(100 \%-67,9 \%=32,1 \%)$ dipengaruhi oleh faktor lain. Didapat $\mathrm{F}$ hitung adalah 18,349, hasil ini semakin memperkuat hasil pengujian hipotesis pertama, kedua, ketiga dan keempat.

Koordinasi mata kaki, kekuatan otot tungkai dan daya ledak otot tungkai merupakan gabungan komponen kondisi fisik dari unsur komponen kondisi fisik yang lain yang saling mendukung dalam suatu unjuk kerja terutama pada saat melakukan shooting permainan sepak bola.Apabila kita melakukan gerakan dari shooting permainan sepak bola yang terdiri dari gerakan menendang bola dengan kekuatan dan kecepatan maksimal serta tendangan yang tepat pada sasaran (gawang lawan) membutuhkan perpaduan koordinasi mata kaki, kekuatan otot tungkai dan daya ledak otot tungkai.Sehingga dapat dikemukakan jika koordinasi mata kaki, kekuatan otot tungkai dan daya ledak otot tungkai saling mendukung dalam melakukan shooting pada permainan sepak bola, maka diharapkan akan menghasilkan shootingyang lebih baik. Oleh karena itu, dengan pentingnya koordinasi mata kaki, kekuatan otot tungkai dan daya ledak otot tungkai, maka dapat disimpulkan adanya hubungan yang signifikan antara koordinasi mata kaki, kekuatan otot tungkai dan daya ledak otot tungkai secara bersama-sama terhadap kemampuan shooting pada permainan sepak bola siswa MAN 2 Kota Makassar.

\section{PEMBAHASAN}

\section{Ada hubungan langsung koordinasi mata kaki terhadap kemampuan shooting pada permainan sepak bola siswa MAN 2 Kota Makassar.}

Dari hasil pengujian hipotesis pertama variabel menunjukkan ada hubungan yang signifikan antara koordinasi mata kaki (X1) terhadap shooting pada permainan sepak bola (Y). Berdasarkan hasil perhitungan diperoleh nilai koefisien korelasi $(r)=0,751$, sehingga dapat membuktikan bahwa teknik shooting pada permainan sepak bola sangat membutuhkan komponen-komponen anggota tubuh seperti koordinasi mata kaki, dimana komponen-komponen tersebut sangat membantu dalam proses melakukan shooting. Karena pada saat seseorang melakukan shooting pada permainan sepak bola membutuhkan koordinasi mata kaki yang baik agar labih mudah dalam mengarahkan bola kedaerah gawang lawan pada permainan sepak bola. 
Hal tersebut berkaitan erat dengan teori yang dikemukakan oleh Widiastuti $(2017: 17)$ "koordinasi merupakan kemampuan untuk melakukan gerakan atau kerja dengan tepat dan efisien. Koordinasi mata tangan merupakan kemampuan biomotorik yang melibatkan beberapa unsurunsur kondisi fisik lainnya"

\section{Ada hubungan langsung kekuatan otot tungkai terhadap kemampuan shooting pada permainan sepak bola siswa MAN 2 Kota Makassar.}

Dari hasil pengujian hipotesis kedua menunjukkan ada hubungan yang signifikan antara kekuatan otot tungkai (X2) terhadap kemampuan shooting pada permainan sepak bola (Y). Berdasarkan hasil perhitungan diperoleh nilai koefisien korelasi $(r)=0,657$, sehingga temuan ini membuktikan bahwa dalam melakukan shooting, kekuatan otot tungkai merupakan faktor penunjang atau faktor pendukung dalam pelaksanaan shooting bola pada permainan sepak bola.

Hal ini sejalan dengan yang dikemukakan oleh Widiastuti (2017:15) kekuatan otot adalah kemampuan otot atau sekelompok otot untuk melakukan satu kali kontraksi secara maksimal melewan tahanan atau beban. Secara mekanis kekuatan otot didefinisikan sebagai gaya (force) yang dapat dihasilkan oleh otot atau sekelompok otot dalam suatu kontraksi maksimal. Kekuatan otot merupakan hal penting untuk setiap orang. Sedangkan Menurut Ismaryati, dkk (2018:111) kekuatan adalah tenaga kontraksi ototyang dicapai dalam sekali usaha maksimal. Usaha maksimal ini dilakukan oleh otot atau sekelompok otot untuk mengatasi suatu tahanan. Kekuatan merupakan unsur yang sangat penting dalam aktivitas olahraga, karena kekuatan merupakan daya penggerak, dan pencegah cedera. Selain itu kekuatan memainkan peranan penting dalam komponen-komponen kemampuan fisik yang lain misalnya power, kelincahan kecepatan. Dengan demikian kekuatan merupakan faktor utama untuk menciptakan prestasi yang optimal.

\section{Ada hubungan langsung daya ledak otot tungkai terhadap kemampuan shooting pada permainan sepak bola siswa MAN 2 Kota Makassar.}

Dari hasil pengujian hipotesis pertama variabel menunjukkan ada hubungan yang signifikan antara daya ledak otot tungkai (X3) terhadap shooting pada permainan sepak bola (Y). Berdasarkan hasil perhitungan diperoleh nilai koefisien korelasi $(r)=0,620$, sehingga dapat membuktikan bahwa teknik shooting pada permainan sepak bola sangat membutuhkan dua komponen anggota tubuh seperti daya ledak otot tungkai, dimana komponen-komponen tersebut sangat membantu dalam proses melakukan shooting. Karena pada saat seseorang melakukan shooting bolamembutuhkan daya ledak otot tungkai yang baik agar labih mudah dalam melakukan shooting pada permainan sepak bola.

Hal ini sejalan dengan yang dikemukakan oleh Widiastuti (2017:16) "Daya eksplosif (Power) adalah gabungan antara kekuatan dan kecepatan atau pengerahan gaya otot maksimum dengan kecepatan maksimum.” Dan teori yang dikemukakan Mulyono Biyakto Atmojo (2015:62) "power adalah kemampuan untuk mengarahkan kekuatan dengan maksimum dalam jangka waktu yang minim".

4. Ada hubungan koordinasi mata kaki,kekuatan otot tungkai dan daya ledak otot tungkaisecara bersama-sama terhadap kemampuan shooting pada permainan sepak bola siswa MAN 2 Kota Makassar.

Dari hasil pengujian hipotesis keempat menunjukkan terdapat hubungan yang signifikan antara koordinasi mata kaki (X1),kekuatan otot tungkai (X2) dan daya ledak otot tungkai (X3) terhadap kemampuan shooting pada permainan sepak bola (Y). Berdasarkan hasil perhitungan diperoleh nilai regresi $\mathrm{R}=0,824$ yang dijelaskan melalui persamaan regresi $\hat{\mathrm{Y}}=-3,722+0,463 \mathrm{X} 1$ $+0,189 \mathrm{X} 2+0,019 \mathrm{X} 3$, untuk nilai R2 (koefisien determinan) $=0,679$. Hal ini berarti 0,679 x 100\% 
$=67,9 \%$ shooting pada permainan sepak bola, koordinasi mata kaki, kekuatan otot tungkai dan daya ledak otot tungkai. Untuk sisanya $(100 \%-67,9 \%=32,1 \%)$ dipengaruhi oleh faktor lain. Didapat $\mathrm{F}$ hitung adalah 18,349, hasil ini semakin memperkuat hasil pengujian hipotesis pertama, kedua, ketiga dan keempat.

Sehingga ini membuktikan bahwa setiap pemain sepak bola harus memiliki komponen anggota tubuh yang ideal di antaranya koordinasi mata kaki, kekuatan otot tungkai dan daya ledak otot tungkai yang baik, sehingga pemain mampu bergerak atau beraktivitas secara efektif dan efisien. Dimana kita ketahui koordinasi mata kaki, kekuatan otot tungkai dan daya ledak otot tungkai adalah gabungan dari unsur-unsur yang sangat penting dalam melakukan beberapa kombinasi gerakan secara lancar atau mulus. Maka peranan koordinasi mata kaki terhadap shooting bola sangat diperlukan karena dapat mendukung untuk mengarahkan bola dengan baik. Begitu pula peranan kekuatan otot tungkaidan daya ledak otot tungkai sangat dibutuhkan dalam melakukan shooting permainan sepak bola, kekuatan otot tungkaidan daya ledak otot tungkain ini berperan saat pemain melakukan tendangan yang keras ke daerah lawan untuk encetak gol. Maka ketika pemain sudah menguasai ketiga komponen tersebut tentunya pemain dapat bermain sepak bola dengan baik khususnya dalam melakukan shooting pada permainan sepak bola.

\section{KESIMPULAN}

(1) Ada hubungan yang signifikan koordinasi mata kaki terhadap kemampuan shooting pada permainan sepak bola Siswa MAN 2 Kota Makassar, dengan nilai $r=0,751(\rho<\alpha=0,05)$

(2) Ada hubungan yang signifikan kekuatan otot tungkai terhadap kemampuan shooting pada permainan sepak bola Siswa MAN 2 Kota Makassar, dengan nilai $r=0,657(\rho<\alpha=0,05)$

(3) Ada hubungan yang signifikan daya ledak otot tungkai terhadap kemampuan shooting pada permainan sepak bola Siswa MAN 2 Kota Makassar, dengan nilai $r=0,620(\rho<\alpha=0,05)$

(4) Ada hubungan yang signifikan secara bersama-sama antara koordinasi mata kaki, kekuatan otot tungkai dan daya ledak otot tungkai terhadap kemampuan shooting pada permainan sepak bola Siswa MAN 2 Kota Makassar, dengan nilai koefisien determinan (R2) = 0,679 atau $67,9 \%$.

\section{DAFTAR PUSTAKA}

Atmojo, Mulyono Biyakto. 2015. Tes \& Pengukuran Pendidikan Jasmani/Olahraga. Surakarta: Penerbit UNS (UNS Press).

Danurwindo,\& dkk.2017. Kurikulum Pembinaan Sepakbola Indonesia. Jakarta: High Performance Unit Persatuan Sepakbola Seluruh Indonesia (HPU PSSI).

Fenanlampir, Albertus Dan Muhammad Muhyi Faruq. 2015. Tes Dan Pengukuran Dalam Olahraga. Yogyakarta: Penerbit CV Andi Offset.

Hadiqie. (2013) Menjadi Pemain Sepak Bola Profesional. Kata Pena.

Hendri, Irawadi. (2011) Kondisi Fisik Dan Pengukuran. Padang.UNP.

Ismaryati. (2016). Tes dan Pengukuran Olahraga. Surakarta: UNS Press.

Juliarta Agus Putu. (2021) Hubungan Antara Kekuatan Otot Tungkai Dan Koordinasi Mata Kaki Dengan Kemampuan Shooting Sepakbola Pada SSB Negaroe U 15 Tahun 2020 Vol 12, No 12021 P-ISSN : 2599-3372 (Print)And E,ISSN: 2614-69932 (Online) Ejournal.Undiksha.Ac.Id. 
Komarudin (2011).Dasar Gerak Sepak Bola. Yogyakarta: FIK UNY

Lhaksanan (2012) Teknik Dan Strategi Footsal Modern. Jakarta Be Campion.

Luxbacher, Joseph (2011). Sepakbola Soccer Step To SuccesAgusta Wibawa Pt RajaGrafindo Persada Jakarta.

Martin,J. (2012) The Best Of Soccer. Maidenhead. United Kingdom: Mayer \& Mayer Soprt Lad Isbn 978-1-84126 -329.

Mulyono M.A. (2014) buku pintar panduan footsal Jakarta Timur: Laskar Askara.

Mylidayu,A.\& Kurniawan F. (2015). Ilmu Kepelatihan Dasar. Bandung: alfabeta

Rahman Abdul.(2012). Hubungan Antara Kekuatan Otot Tungkai Kecepatan Lari Dan Kelincahan Dengan Keterampilan Mengiring Bola Pada Siswa Sekolah Sepakbola (SSB)Piyaman Wonosari. Yogyakarta:FIK UNY

Rollin R. Alegi \& dkk (2019) Football United Kingdom

Santoso Giriijoyo (2015). Manusia Dan Olahraga. Bandung: Penerbit Institut Teknologi Bandung

Sugiyono (2017) Metode Penelitian Pendidikan (Pendekatan Kualitatif,Kuantitatif,Dan R\&D). Penerbit CV.Alfabeta:Bandung

Sukadiyanto (2010) Pengantar Teori Dan Meteodologi Melatih Fisik. Yogyakarta: Universita Negeri Yogyakarta

Sepdanius,Endang (2019) tes dan pengukuran olahraga

Watson,S. (2015) Football Cooaching Manual. United Kingdom: Footy4kids.

Widiastuti. 2017. Tes dan Pengukuran Olahraga. Depok: Penerbit PT Rajagrafindo Persada. 